\title{
Impact of Liquidity on Profitability: A Comprehensive Case of Pakistan's Private Banking Sector
}

\author{
Muhammad Shaukat Malik ${ }^{1}$, Mustabsar Awais ${ }^{1}$ \& Aisha Khursheed ${ }^{2}$ \\ ${ }^{1}$ Alflah Institute of Banking and Finance, Bahaudin Zakariya University, Pakistan \\ ${ }^{2}$ University of Education, Lahore, Multan Campus, Multan, Pakistan \\ Correspondence: Aisha Khursheed, University of Education, Lahore, Multan Campus, Pakistan. Tel: \\ 920-619-210-040. E-mail: aisha.khursheed@ue.edu.pk
}

Received: December 24, 2015

Accepted: February 2, 2016

Online Published: February 25, 2016

doi:10.5539/ijef.v8n3p69

URL: http://dx.doi.org/10.5539/ijef.v8n3p69

\begin{abstract}
The subject of liquidity-profitability interchange is well recognized in the literature. This study was conducted to inspect the trade-off between liquidity and profitability in private sector banks of Pakistan. The study was carried on twenty two private sector banks registered under State bank of Pakistan during the time period of 2009-2013. Three models were specified and estimated using Ordinary Least Squares (OLS) technique. The empirical results revealed that there is a statistically significant relationship between bank liquidity measures and return on assets. However, when return on equity and return on investment was used as proxy for profitability, the relationship became statistically insignificant. It has been recommended that the banks should assess and restructure their strategies for managing liquidity. This will not only improve yields on shareholders equity but will also enhance the use of the assets of the bank.
\end{abstract}

Keywords: liquidity, profitability, trade-off , banks, optimal liquidity

\section{Introduction}

\subsection{Introduction to the Problem}

In this world the banks are the most powerful financial institutions/sectors that play the significant role in economic development. We can define bank as an organization for raising the fund for the public and giving customer goods and securities on credit. It also discounts the bills for the important financial institutions. The liquidity of an organization is considered as most important element for it to pay its current liabilities. It includes payment of duties and the other financial expenses which are considered as short term. There is an inverse relationship between profitability and liquidity ratio. If we want to increase profitability then we have to sacrifice liquidity. At the same time increased liquidity will be on the cost of profitability. According to (Amengor, 2010) in commercial banks the liquidity basically represents the capacity to settle its commitments at maturity time. These commitments include lending and investment commitments, any kind of withdrawals, deposits made by account holders, and accrued liabilities.

(Eljelly, 2004) described liquidity as the ability of a deposit money bank to pay its short term obligation to its depositors and creditors on demand or at maturity. On the other hand profitability is the measure of the difference between income and the bank operating expenses. It can be concluded by the work of (Eljelly, 2004) that liquidity ratio and profitability can be like two forces having differing objectives which at all times exert pressure to pull the bank apart.

It has been explained by (Olagunju, David, \& Samuel, 2012) that profitability and liquidity are very important to the main tax authorities, creditors and shareholders. The business men are interested to become the shareholders in the bank. Investors gain the profitability by their investment done in bank and this can be determined by their return on investment. While the liquidity is the ability to fulfill the customer's or depositor's withdrawal needs, which is usually on demand or on a short notice as the case may be. The tax authorities are interested in profitability of the banks in order to determine the appropriate tax obligation.

(Soenen, 1993) described that liquidity ratio work with cash and near cash assets of a business on one side, and the payment obligation on the other side payment. The near cash assets normally include receivables from 
customers and inventories of complete goods and natural materials. Operating cash flows produced by assets will affect firm liquidity position.

\subsection{Importance of the Problem}

The impact of Liquidity on the Profitability is to rationalize the assets or investments of the firm or financial institution in such a way that the firm or institution may be able to pay the quick obligations due upon it with out any heavy loss. The arrangement of investments will lead to reap an economical profit and in no phase will have to face any sort of slump. The main objective of this study is to find the impact of liquidity on profitability.

\subsection{Relevant Scholarship}

\subsubsection{Liquidity}

The term liquidity is basically a technique which is used by an organization to convert its assets (current) into cash. Whenever a firm/organization needed to meet its financial obligations, it converts its current assets into cash form to pay the due liabilities at maturity date. As and when the bank needed to pay its short term obligations to its debtors and creditors/suppliers, it must have an ability to satisfy it's creditors for this purpose, and this ability is named as "Liquidity" of a bank. This can be defined in simple words as under: A technique or procedure which is adopted by a firm or an organization or any financial institution to convert its assets into to cash for payment of near term obligation livid upon. (Van Horne \& Wachowicz, 2008) described that organizations having current assets in less quantity will face problems in continuing it's operations on the other hand if the number of currents assets is too high, this shows that the return on investment for the organization is not in unspoiled state.

(Anyanwu, 1993) defined liquidity as the ability of a firm to convert it's asset into cash within the short time and without the loss of value. Liquidity ratio plays a very important role in every business because banks usually operate with large funds borrowed from depositors in form of demand deposits and time deposits. (Olagunju et al., 2012) explained that liquidity means the ability of a bank to meet financial commitments at a reasonable price at all times. Banks having money when they need to satisfy the withdrawal needs of their customers.

(Carlin, Kogan, \& Lowery, 2013) considers that liquid assets should be marketable securities. Liquidity of assets means that they are expected to be converted to cash easily and pay out the liability. Another quality of liquid assets is price stability. Based on the characteristic, bank deposits and short term securities are more liquid than equity investments due to the fact that the prices of the former are fixed than the prices of short term securities.

\subsubsection{Profitability}

The issue of profitability is a contentious subject that a bank has to consistently face. (Heibati, Seid Noorani, \& Dadkhah, 2009) explained profit as the difference among expenditures and returns during a fixed period of time, normally comprised of one year. They argued that a business behaves like living i.e. it stay alive and grows. Therefore, it is significant that a bank produces income for its continuous survival and growth. It is also essential that sufficient income must be produced to sustain the operations of the organization that will lead towards further expansion and growth.

(Agbada \& Osuji, 2013) consider planning for corporate profit as one of the most challenging and extensive aspect performed by bank management just because of the involvement of numerous variables in the decision making process, which are generally not in the control of the bank. They also argued that profit planning can be even more complex if it is done in highly challenging economic environment.

It has been described by (Tabari, Ahmadi, \& Emami, 2013) that profitability is measured by two substitute measures. First is the return on asset (ROA) as measured by the ratio of profits to total assets, and the second is return on equity (ROE). It is generally believed that return on assets ROA reveals the capacity of the assets of the banks to produce profit, though this estimate can be biased due to off-balance-sheet activities. According to (Saleem \& Rehman, 2011) profitability can also be measured using return on investment (ROI)

\subsubsection{Theories of the Relationship between Liquidity and Profitability}

Various theories have been presented to provide awareness for the association between liquidity and profitability of banks. The straightforward query which the underlying theories tried to respond is how does liquidity affect profitability in banking?

(Osborne, Fuertes, \& Milne, 2009) suggested that greater liquidity is usually expensive for banks, suggesting that greater liquidity decreases profitability. However, according to the trade-off theory, 
Bank's risk can be reduced due to higher liquidity and in future the premium required compensating investors for the costs of reducing bankruptcy risk (Osborne, Fuertes, \& Milne, 2012). They also argued that during business cycle bank's optimal liquidity level vary, naturally increasing when expected costs of distress are expected to be higher, the association between profitability and liquidity is possible to be extremely recurring, showing more positive results through the stages of distress as banks that try to increase their liquidity position also increase their profitability. So, there can be a negative or positive relationship between liquidity and profitability in the short-run which depends on bank's current liquidity position in comparison to its optimal liquidity level.

According to (Flannery \& Rangan, 2008) proclaim that if it is possible for banks to attain their optimal liquidity level then certainly there will not exist any short-run relationship. As any change in liquidity has no impact on profitability. However, in the long run, regulatory requirements for liquidity may be a requisite. This suggests that greater liquidity position only decreases profitability in case if banks are beyond their optimal liquidity level, for example due to regulatory requirements imposed by regulatory authorities or unanticipated events.

In support of the above study, (Osborne et al., 2012) discoursed that banks' optimal liquidity level raises through phases of distress in banking sector. As the cost of bankruptcy rises during such phases of distress.

(Agbada \& Osuji, 2013) clarified the relationship between liquidity and profitability more briefly. They argued that it is more safe for banks to maintain high amount of cash reserves against the deposits held by the bank. As this reserve is an idle money they will not be earning any profit on it. At the same time if they adopt the policy of investing all to increase the profit they may face illiquidity problem if customers demand much cash in a particular time.

It can be concluded that good banker must have to maintain a harmony between these two conflicting objectives by investing in a very well diversified good portfolio mix.

\subsection{Hypotheses and Their Correspondence to Research Design}

There is an inverse relationship between the Profitability Ratio and Liquidity Ratio of a firm. As a firm decreases its liquidity ratio, it's profit boost up and firm reaps a huge amount of profit from its investments (long term investments) and when a firm needed to liquidize it's assets for the payment of its obligations it has to reduce its profit, which cause to bring a decline in the Profitability Ratio. This situation provides bad impact on the goodwill of the firm. But on the other hand liquidity also proved fruit full when it saves the firm to flop or close.

\section{Method}

\subsection{Research Design}

This study is quantitative explanatory study. The study used panel data analysis of the variables mentioned in the models. In essence, the purpose is to give a projection of the examined phenomenon with an insight to indorse a suitable liquidity management strategy for the banks (Alvesson, 2009).

\subsection{Specification of Model}

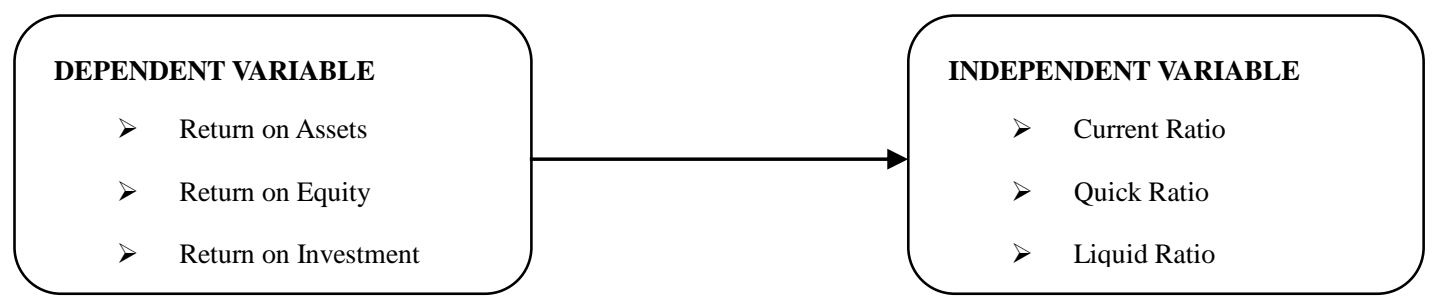

\subsection{Dependent Variable}

$$
\begin{gathered}
\text { Return on Asset }(\text { ROA })=\frac{\text { Net } \text { profit before tax }}{\text { Total Assets }} \\
\text { Return on Equity }(\text { ROE })=\frac{\text { Net profit before tax }}{\text { Share holder equity }} \\
\text { Return on investment }(R O I)=\frac{\text { Net profit before tax }}{\text { Investments }}
\end{gathered}
$$




\subsection{Independent Variables}

$$
\begin{gathered}
\text { Current Ratio }=\frac{\text { Current Assets }}{\text { Current Liabilities }} \\
\text { Acid test ratio or Quick ratio }=\frac{\text { Current Assets-inventories }}{\text { Current Liabilities }} \\
\text { Liquid ratio }=\frac{\text { Cash }+ \text { Investments }}{\text { Current Liabilities }}
\end{gathered}
$$

\subsection{Data Collection}

In this study, annual data (from 2009 to 2013) of twenty two Financial Institutions from private banking sector in Pakistan which are registered under state bank of Pakistan are evaluated to evaluate the relationship between profitability and liquidity.

\subsection{Statistical Model}

This research is evaluating the effect of liquidity on profitability by examining the financial data of private banking sectors of Pakistan by selecting 22 banks registered under state bank of Pakistan during the period from 2009-2013 by applying Linear Regression using STATA 14.

$$
\begin{aligned}
& R O A=\alpha_{1}+\beta_{1} C R+\beta_{2} L R+\beta_{3} L R+U i \\
& R O E=\alpha_{1}+\beta C R+\beta_{2} Q R+\beta_{3} L R+U i \\
& R O I=\alpha_{1}+\beta_{1} C R+\beta_{2} Q R+\beta_{3} L R+U i
\end{aligned}
$$

Where:

ROA: Return on Assets,

ROE: Return on Equity

ROI: Return on Investment

$\boldsymbol{\alpha}$ : The constant

$\boldsymbol{\beta}$ : The regression coefficient.

\section{Results}

The data analysis used the Panel Method is performed OLS assuming the Slope Co-efficient and Intercept are same time and entity.

\subsection{Model 1}

\begin{tabular}{llllll}
\hline Sr. no & Dependent & Independent & Slope Co efficient $(\beta)$ & P-vale & $\mathbf{R}^{\mathbf{2}}$ \\
\hline $\mathbf{1}$ & & CR & -0.0428881 & $0.048^{*}$ & \\
$\mathbf{2}$ & ROA & QR & 0.0636181 & $0.003^{*}$ & 0.1198 \\
$\mathbf{3}$ & & LR & 0.0393392 & 0.207 & \\
\hline
\end{tabular}

\subsection{Model 2}

\begin{tabular}{llllll}
\hline Sr. no & Dependent & Independent & Slope Co-efficient $(\beta)$ & P-vale & $\mathbf{R}^{\mathbf{2}}$ \\
\hline $\mathbf{1}$ & & CR & 1.605992 & 0.373 & \\
$\mathbf{2}$ & ROE & QR & 0.7932836 & 0.657 & 0.0181 \\
$\mathbf{3}$ & & LR & -1.268141 & 0.626 & \\
\hline
\end{tabular}

\subsection{Model 3}

\begin{tabular}{llllll}
\hline Sr. no & Dependent & Independent & Slope Co-efficient $(\beta)$ & P-value & $\mathbf{R}^{2}$ \\
\hline $\mathbf{1}$ & & CR & -0.1682864 & 0.549 & \\
$\mathbf{2}$ & ROI & QR & 0.0445056 & 0.871 & 0.0177 \\
$\mathbf{3}$ & & LR & 0.0445056 & 0.439 & \\
\hline
\end{tabular}




\section{Discussion}

In the light of the above tabulated data it has been suggested that there is a strong relationship between these ratios of the firm. There is a point that keeping liquid asset reduces profitability.

The results show form linear regression analysis ROA significantly affected by three ratio current ratio, quick ratio, liquidity ratio but ROE is not affected by the current ratio, liquidity ratio and quick ratio.

As a conclusion from the $1^{\text {st }}$ Model analysis, ROA is affected by the three ratio Current Ratio Quick Ratio Liquidity Ratio And the three ratios in p-value is current ratio is less then 5\%, and quick ratio and current ratio is less then 5\%. The ROA is affected three ratios in CR, LR, QR to analysis of private banking sector in Pakistan registered under state bank of Pakistan. ROA is directly affected by the CR -0.0428881 , QR 0.0636181 and LR 0.0393392 and Standard error (S.E) is CR 0.0214848, QR 0.0210343, LQ 0.0310188 and P-value CR 0.373, QR 0.003 and LR 0.207 and R-square value 0.1198. Through the evaluation of the second Model, there is no sufficient impact of the ROE on Liquidity Ratios i-e no major effect of Current Ratio, Liquidity Ratio and Quick Ratio on Return on Equity near is no P-value came less then 0.05 all are the over then 0.05 . And the standard error (S.E) is CR 1.794949, QR 1.757315 and LR 2.591474 and R-square value 0.0181. The third Model is concluding that ROI is no effect of Current Ratio, Quick Ratio and Liquidity Ratio because the P-value is above then 5\%. And the standard error (S.E) is CR 0.2800711, QR 0.274199 and LR 0.4043552 and R-square value 0.0177 . Thus liquidity ratios affect on the ROI positive proportion after analysis of the private banking sectors registered under state bank of Pakistan. Value of all three ratios -0.4338 the value of independent variables values of Current Ratio, Quick Ratio and Liquidity Ratio show that in Model means that Return on Investment is freely affected by 0.0445056 Quick Ratio and 0.0445056 Liquidity Ratio positive effect but negative by QR 0.1682864. So standard error (S.E) CR 0.28000711, QR 0.274199 and LQ 0.4043552 and p-value are shown in Model three.

\section{Conclusion}

As a conclusion from the above working and calculation by analyzing the data taken from the private banking sector registered under state bank of Pakistan through the above mentioned Models, we reached at a step that obviously there is negative relationship between the Profitability Ratio and the Liquidity Ratio. Some-times, there may be a weak positive relation between these ratios.

\section{References}

Agbada, A. O., \& Osuji, C. (2013). The efficacy of liquidity management and banking performance in Nigeria. International Review of Management and Business Research, 2(1), 223.

Alvesson, M. (2009). (Post-) positivism, social constructionism, critical realism: Three reference points in the philosophy of science. In M. Alvesson, \& K. Sköldberg (Eds.), Reflexive methodology: New vistas for qualitative research. London: SAGE.

Amengor, E. (2010). Importance of Liquidity and Capital Adequacy to Commercial Banks. A Paper Presented at Induction Ceremony of ACCE, UCC Campus.

Anyanwu, J. C. (1993). Monetary Economics: Theory, policy, and Institutions. Hybrid Publishers.

Carlin, B. I., Kogan, S., \& Lowery, R. (2013). Trading complex assets. The Journal of Finance, 68(5), 1937-1960. http://dx.doi.org/10.1111/jofi.12029

Eljelly, A. M. (2004). Liquidity-profitability tradeoff: An empirical investigation in an emerging market. International Journal of Commerce and Management, 14(2), 48-61. http://dx.doi.org/10.1108/10569210480000179

Flannery, M. J., \& Rangan, K. P. (2008). What caused the bank capital build-up of the 1990s? Review of Finance, 12(2), 391-429. http://dx.doi.org/10.1093/rof/rfm007

Heibati, F., Seid Noorani, M., \& Dadkhah, S. (2009). Evaluation of private banks compared to banks performance of countries around Arabic Gulf. Journal of Economic, 6, 91-108.

Olagunju, A., David, A. O., \& Samuel, O. O. (2012). Liquidity Management and Commercial Banks' Profitability in Nigeria. Research Journal of Finance and Accounting, 2(7-8), 24-38.

Osborne, M., Fuertes, A., \& Milne, A. (2009). Capital and profitability in banking: Evidence from US banks. Working Paper Series. 
Osborne, M., Fuertes, A. M., \& Milne, A. (2012). In good times and in bad: Bank capital ratios and lending rates. http://dx.doi.org/10.2139/ssrn.1971324

Saleem, Q., \& Rehman, R. U. (2011). Impacts of liquidity ratios on profitability. Interdisciplinary Journal of Research in Business, 1(7), 95-98.

Soenen, L. A. (1993). Cash conversion cycle and corporate profitability. Journal of Cash Management, 13, 53-53.

Tabari, N., Ahmadi, M., \& Emami, M. (2013). The Effect of Liquidity Risk on the Performance of Commercial Banks. International Research Journal of Applied and Basic Sciences, 4(6), 1624-1631.

Van Horne, J. C., \& Wachowicz, J. M. (2008). Fundamentals of financial management. Pearson Education.

\section{Copyrights}

Copyright for this article is retained by the author(s), with first publication rights granted to the journal.

This is an open-access article distributed under the terms and conditions of the Creative Commons Attribution license (http://creativecommons.org/licenses/by/3.0/). 